\title{
Population development of Twig Borer Moth, Kermania pistaciella Amsel, 1964 (Lepidoptera: Oinophilidae) and its Pupae Parasitoid Microchelonus fissilis Tobias, 1964 (Hymenoptera: Braconidae) on Pistachio in Turkey
}

\author{
Halil BOLU ${ }^{* 1}$ \\ ${ }^{1}$ Dicle University, Faculty of Agriculture, Department of Plant Protection, 21280 Sur/ Diyarbakir-Turkey.
}

Abstract

Original scientific paper Twig borer moth, Kermania pistaciella Amsel, 1964 is an important of pistachio pest in Turkey. This study was conducted done in four pistachio orchards from 1992-1993 in the Şanlıurfa province of Turkey. The objective was to quantify damage caused by K. pistaciella in pistachio and measure and population development of $K$. pistaciella and its specific pupae parasitoid Microchelonus fissilis Tobias, 1964.

$K$. pistaciella overwinter as mature larvae in galleries in 1-2 yr old shoots; beginning in March, larvae leave galleries and pupae on the shoots in which they overwintered. Adult flight occurred in April and May. First flight of M. fissilis occurred 1-2 wks after first flight of K. pistaciella. One hundred shoots were inspected in each experiment orchard and maximums of 35 pupae were observed in 1992 in Tülmen village, and 40 pupae 1993 in Altınova village. The maximum rate of parasitism was 45\% in 1992 in Ayran village and 57\% in 1993 in Altınova village. The maximum damage caused by each generation of K. pistaciella larvae was determined as $45 \%$ in 1992 in Altınova village and 38\% in 1993 at the same village.

Keywords: Kermania pistaciella, Microchelonus fissilis, Pistachio, Şanlıurfa, Turkey.

\section{Introduction}

Pistachio can grow in stony soils with high lime content under arid conditions that other crops cannot withstand grow up difficulties. Pistacia terebinthus L. and $P$. khinjuk Stocks is native trees in Southeastern Anatolia in Turkey that support commercial pistachio production. Approximately $90 \%$ of total pistachio production of Turkey is obtained from this region (Anonymous, 2019), but productivity is lower than the world average due to harmful insects.

Davatchi (1958) reported that pests caused 50\% crop loss in pistachio in Iran, which suggests the importance of insect damage for pistachio production. In Turkey, plant protection activities have been continued since 1950s in pistachio growing areas.

In the middle of $1980 \mathrm{~s}$ the pest composition was changed because of disturbed natural balance. At the beginning of 1980s, Pistachio leafhopper, Idiocerinus stali was the main pest of pistachio orchards but the situation has changed into the advantage of Pistachio psyllid, Agonoscena pistaciae. In recent years, besides A. pistaciae, Pistaciae twig borer, Kermania pistaciella is also become to the main pest status. In Turkey, K. pistaciella is an exceptionally important pest for pistachio among other pests (Günaydın, 1978; Bolu, 2002, Özgen et al., 2012; Yanık and Yıldırım, 2016; Şimşek and Bolu, 2016).

In this study, we aimed to determine population development and rate of damage of $K$. pistaciella and population development of its natural enemy $M$. fissilis.

\section{Material and Method}

This study was carried out in İlhan and Tülmen of center, and Altınova and Ayran villages of Birecik district of Şanlıurfa province.

To eliminate edge effects, the first four rows were not sampled the fifth tree was selected for sampling. Totally 25 trees were selected as sampling from each orchard.

Trees selected for sampling were inspected once week between March and September. Cocoons were sought on four one- or two-years-old four shoots of each tree for a total of 100 shoots on 25 trees. Adult emergence was determined by presence of the pupae skin at the tip of the cocoon, and parasitoid emergence was determined by an emergence opening that was circular and pupae skin that was absent at the tip of the cocoon (Küçükarslan, 1966). In addition, 100 one-year-old shoots were collected, brought to the laboratory, and inspected by cutting to find generation larvae. Thus, cocoon, adult-emerged cocoon, parasitoid-emerged cocoon and damage by new generation larvae were determined.

Statistical Analysis. Population development of Kermania pistaciella and its pupae parasitoid Microchelonus fissilis was determined by analysis of variance (ANOVA) to identify significant differences within each variety.

\section{Results and Discussion}

Population Development of Kermania pistaciella Amsel. In 1992 the overwintering larvae of K. pistaciella exited from galleries during the first week of March and 
pupated. Exiting from the shoots continued until the second or third week of May. Küçükarslan (1966) reported that mature larvae started to emerge from shoots during the last week of the February. Population development of $K$. pistaciella and M. fissilis are given in Figure 1.

One hundred shoots were inspected in each experiment orchard in 1992 and a maximum of 23 pupae were observed on 26 March at Altınova, 15 pupae on 15 April at Ayran, 22 pupae on 16 April at İlhan and 35 pupae on 26 March at Tülmen.

In 1992 fewer pupae of K. pistaciella at were found the orchard in Ayran than in other orchards. However, in this orchard more damaged shoots were found than in other orchards. These results are connected higher damages of $K$. pistaciella in the previous years.

One species of parasitoid was obtained from cultured pupae of $K$. pistaciella, and it was identified as Microchelonus fissilis TOB. (Hymenoptera: Braconidae) by Prof. Dr. Ahmet Beyarslan University of Trakya,
Biology Department. Küçükarslan (1966) reported Mirax sp. and Microchelonus sp. (Hymenoptera: Braconidae) as parasitoids of $K$. pistaciella in pistachio orchards. $K$. pistaciella is a new host record for Microchelonus fissilis.

In 1992 adult emergence of K. pistaciella occurred during the last week of March in Ayran, during the first week of April in Altınova, during the second week of April in Ayran, and during the third week of April in Tülmen. One to two weeks after first flight of $K$. pistaciella, its parasitoid M. fissilis emerged. In 1992 parasitism rate were $31 \%$ at Altınova, $45 \%$ at Ayran, 30\% at İlhan and 29\% at Tülmen. Küçükarslan (1966) has reported similar parasitism rate of $21 \%-59 \%$

$K$. pistaciella and $M$. fissilis were looking of population development analysis results in 1992-year Table 1. Pupae and adult emerged pupae were an important finding between differences. Although parasitized pupae was difference finding İlhan other orchard.)

Table 1. Population Development of K. pistaciella and M. fissilis at 1992 in Şanliurfa

\begin{tabular}{lccc}
\hline & \multicolumn{3}{c}{ Table 1. Population Development of K. pistaciella and M. fissilis at 1992 in Şanliurfa } \\
\hline Orchard & Pupae & Adult Emerged Pupae & Parasitized Pupae \\
Atınova & $11.13 \pm 2.95 \mathrm{a}$ & $8.33 \pm 2.56 \mathrm{a}$ & $4.22 \pm 1.21 \mathrm{a}$ \\
Ayran & $7.88 \pm 2.25 \mathrm{a}$ & $5.78 \pm 2.20 \mathrm{a}$ & $4.11 \pm 1.47 \mathrm{a}$ \\
İlhan & $7.75 \pm 3.00 \mathrm{a}$ & $4.44 \pm 1.83 \mathrm{a}$ & $1.78 \pm 0.80 \mathrm{~b}$ \\
Tülmen & $13.75 \pm 4.49 \mathrm{a}$ & $8.56 \pm 3.38 \mathrm{a}$ & $2.89 \pm 1.37 \mathrm{a}$ \\
\hline
\end{tabular}

Means within column followed by the same letter are not significantly different (Duncan test at 5\% level)

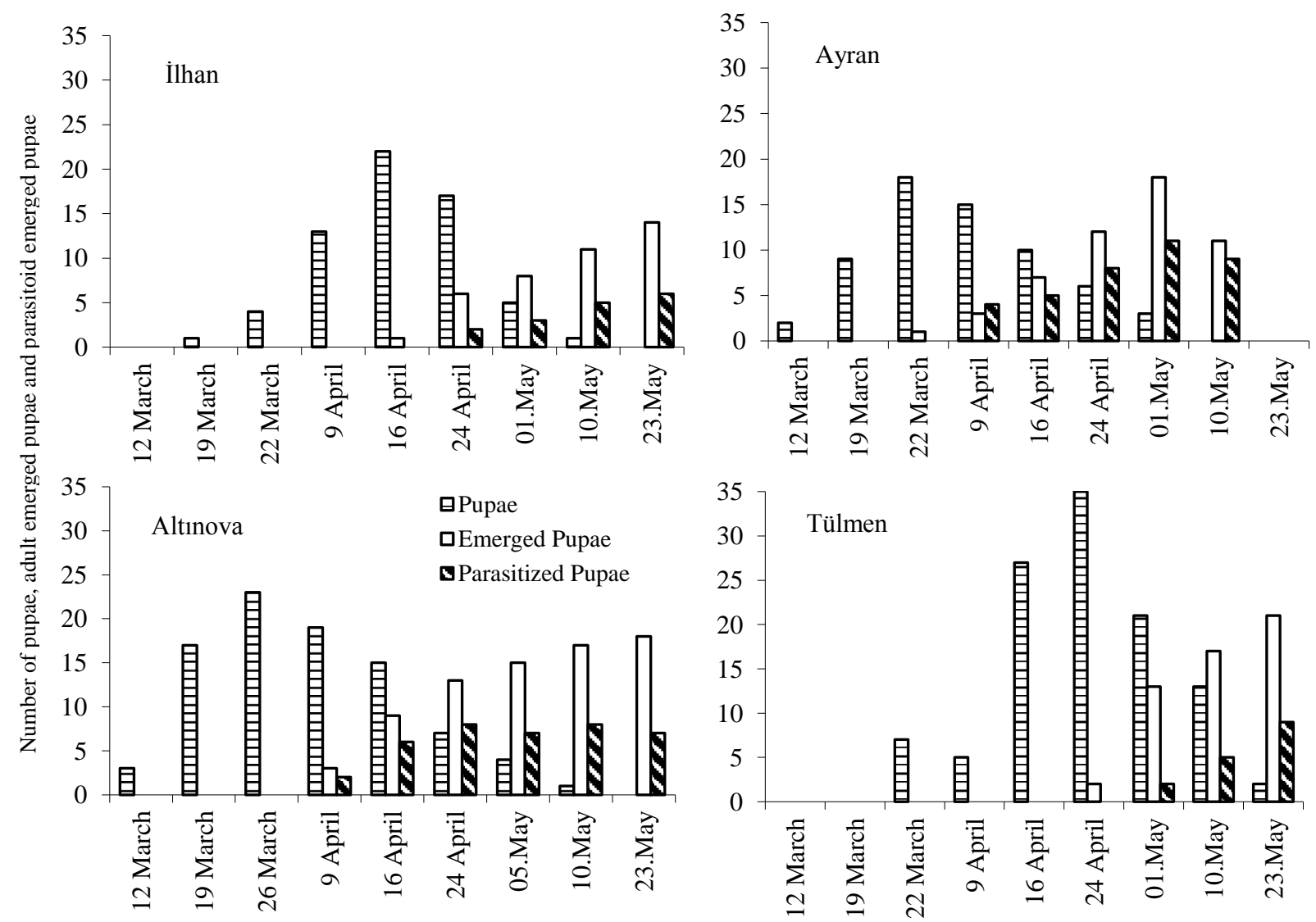

Figure 1. Population development of K. pistaciella and M. fissilis during 1992 in Şanlıurfa 
Population development of $K$. pistaciella and its parasitoid were observed in 1993 at the same orchards (Figure 2). One hundred shoots were inspected in each orchard in 1993 and a maximum 40 of pupae were observed on 1 April at Altınova, 19 pupae on 8 April in Ayran, 12 pupae on 8 April at İlhan and 32 pupae on 22 April at Tülmen.

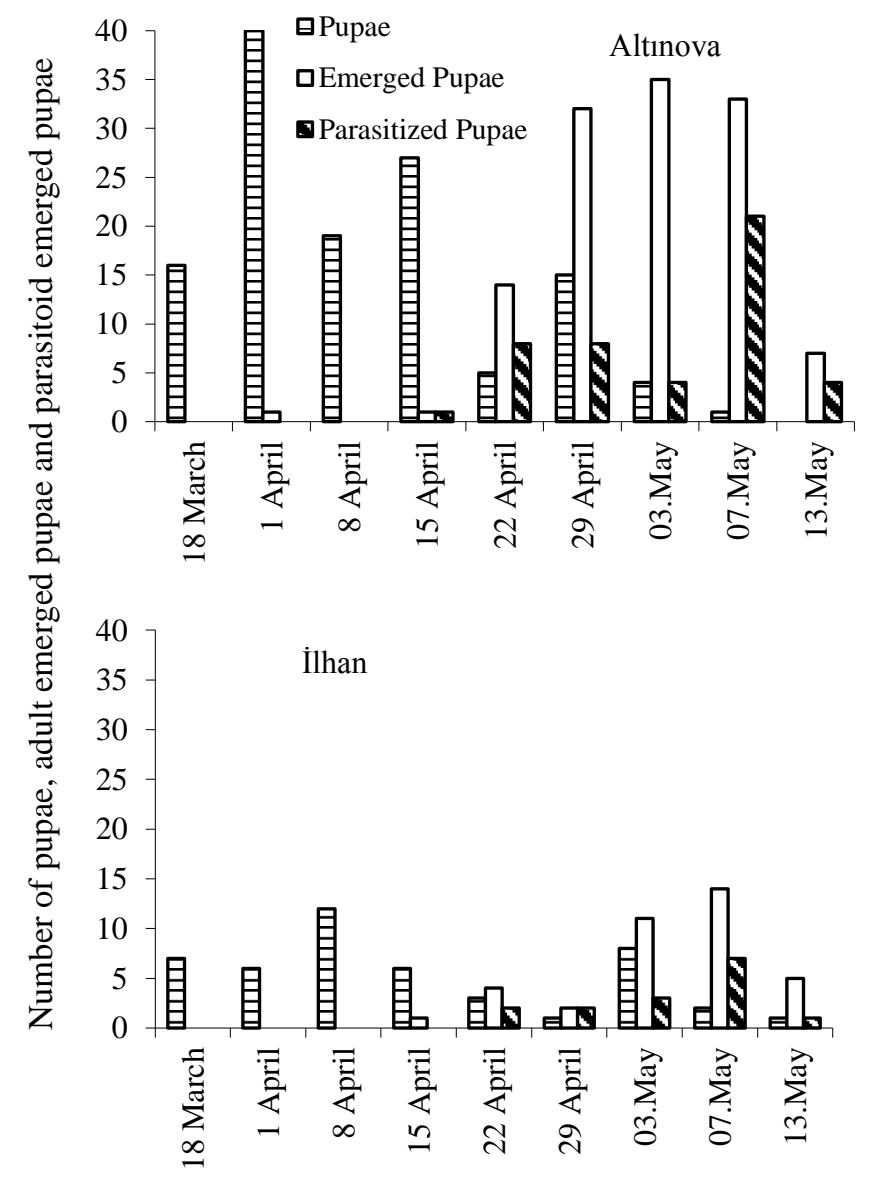

In this year more pupae of $K$. pistaciella were observed than in 1992 at Altınova, and at İlhan fewer pupae were detected. However at Ayran and Tülmen the number of pupal of $K$. pistaciella did not change. The change in number of pupae in Altınova and İlhan was related to with parasition rate. K. pistaciella and M. fissilis were looking of population development analysis results in 1993 year Table 2 .
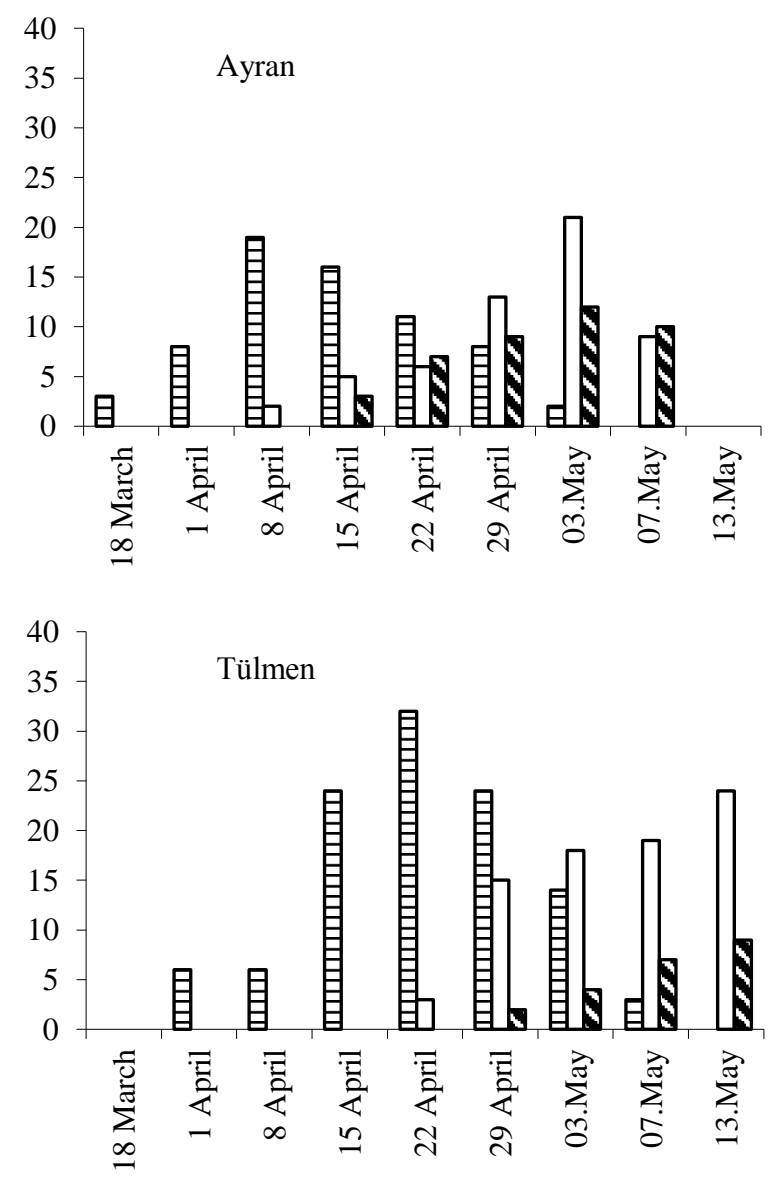

Figure 2. Population development of K. pistaciella and M. fissilis at 1993 in Şanlıurfa

Table 2. Population Development of K. pistaciella and M. fissilis at 1993 in Şanliurfa

\begin{tabular}{lccc}
\hline & \multicolumn{3}{c}{ Stage (Mean \pm SE) } \\
\hline Orchard & Pupae & Adult Emerged Pupae & Parasitized Pupae \\
\hline Atınova & $15.88 \pm 4.62 \mathrm{a}$ & $15.25 \pm 5.55 \mathrm{a}$ & $5.75 \pm 2.45 \mathrm{a}$ \\
Ayran & $8.38 \pm 2.38 \mathrm{ab}$ & $7.00 \pm 2.55 \mathrm{ab}$ & $5.13 \pm 1.76 \mathrm{a}$ \\
İlhan & $5.63 \pm 1.27 \mathrm{~b}$ & $4.63 \pm 1.85 \mathrm{~b}$ & $1.88 \pm 0.83 \mathrm{~b}$ \\
Tülmen & $13.63 \pm 4.16 \mathrm{a}$ & $9.88 \pm 3.57 \mathrm{ab}$ & $2.75 \pm 1.26 \mathrm{ab}$
\end{tabular}

Means within column followed by the same letter are not significantly different (Duncan test at $5 \%$ level)

İlhan was different finding pupae Altınova and Ayran, It was different finding with Tülmen. Ayran, İlhan and Tülmen were emerged pupae different finding in Altınova. İlhan and Tülmen were parasitized pupae different Altınova and Ayran.
In $1992,43 \%$ of pistachio shoots at Altınova were damaged by $K$. pistaciella $45 \%$ at Ayran, 29\% at İlhan and 35\% at Tülmen. In 1993, 38\% of shoots were damaged by $K$. pistaciella at Altınova, $25 \%$ at Ayran, $15 \%$ at İlhan and $32 \%$ at Tülmen (Figure 3) 


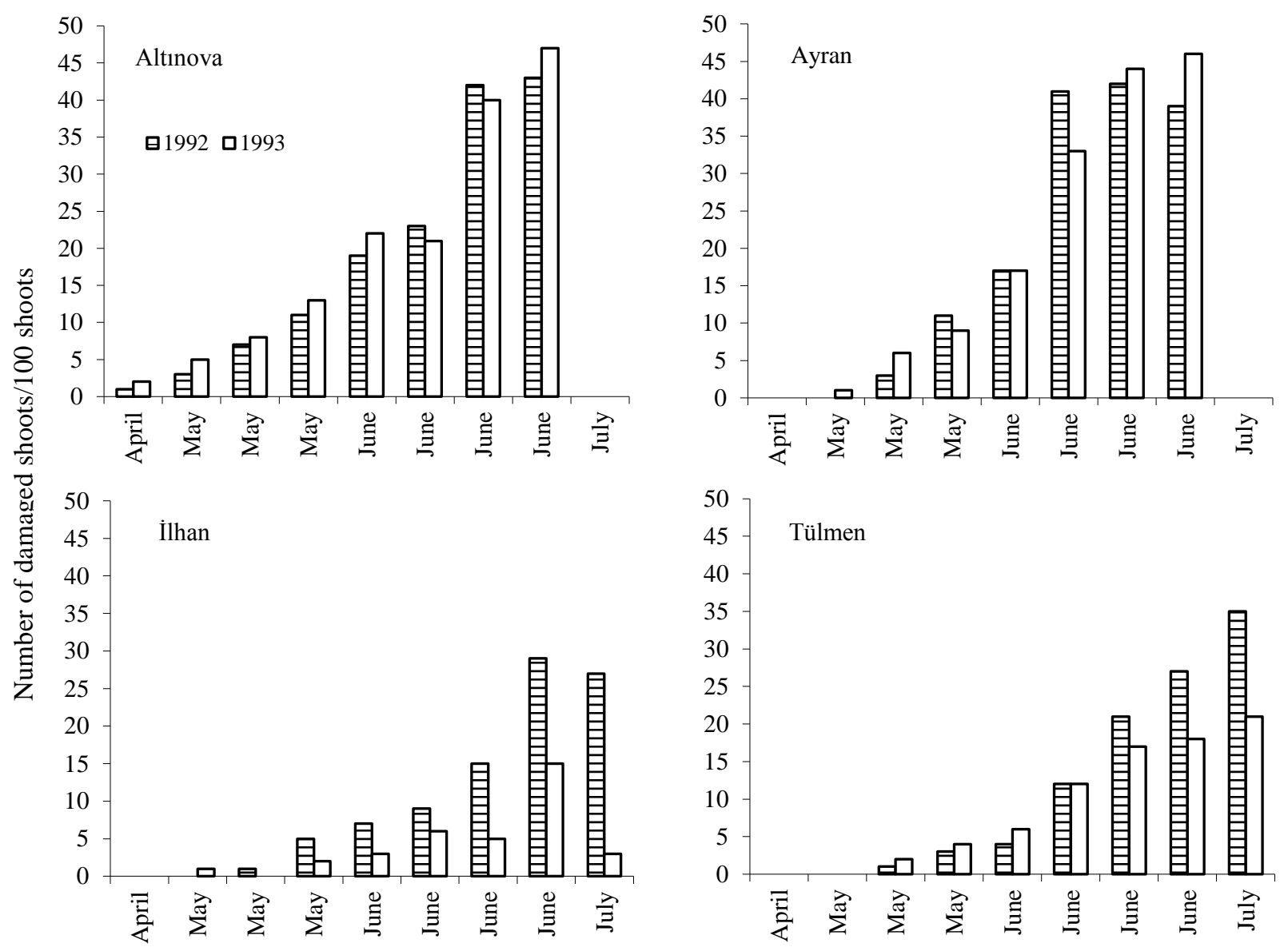

Figure 3. Damage rate of Kermenia pistaciella at the orchards at 1992-1993 in Şanlıurfa

Table 3. Damage rate of Kermania pistaciella at the orchards at 1992-1993 in Şanliurfa

\begin{tabular}{lcc}
\hline \multicolumn{3}{c}{ Damaged\%(Mean \pm SE) } \\
\hline Orchard & 1992 & 1993 \\
\hline Atınova & $18.63 \pm 5.84 \mathrm{a}$ & $19.75 \pm 5.79 \mathrm{a}$ \\
Ayran & $19.13 \pm 6.63 \mathrm{a}$ & $19.50 \pm 6.69 \mathrm{a}$ \\
İlhan & $11.63 \pm 3.94 \mathrm{a}$ & $4.38 \pm 1.67 \mathrm{~b}$ \\
Tülmen & $12.88 \pm 4.70 \mathrm{a}$ & $10.00 \pm 2.85 \mathrm{ab}$ \\
\hline
\end{tabular}

Means within column followed by the same letter are not significantly different (Duncan test at 5\% level)

Küçükarslan (1966) reported that $K$. pistaciella damaged $35 \%$ of stems in Birecik pistachio orchards. Günaydın (1978) reported that it damaged 5.5\% of stems in Adiyaman (Center and Besni districts), 2.6\% in Diyarbakır (Lice district), 20.7\% in Mardin, 21.5\% in Siirt (Center and Şirvan districts), 19.8\% in Şanlıurfa and 35$37 \%$ in Birecik. These results are consistent with our findings.

In southeastern Anatolian pistachio orchards, $K$. pistaciella was considering an important pest (Adiyaman, Diyarbakır, Gaziantep, Siirt and Şanlıurfa provinces) by Küçükarslan (1966), Günaydın (1978), Bolu (2002), Özgen et al., (2012) and Yanık and Yıldırım (2016), Şimşek and Bolu (2016) and Beyarslan and Şahan (2019).
According to our research, the damage of $K$. pistaciella consistent natural enemies does not appear to control this pest adequately. Chemical control of this pest is likely.

K. pistaciella was showing of damage rate in 1992-93 years. The orchards between were passing difference. Only it was difference finding Altınova and Ayran in 1993 year.

\section{Acknowledgements}

I thank Prof. Dr. Ahmet Beyarslan for identification of Microchelonus fissilis TOB.. 


\section{References}

Anonymous. 2019. Agricultural Structure and Production. Turkey Minister Statistics Institute, Ankara.

Beyarslan, A. and Y. B. Şahan, 2019. A new species of Chelonini (Hymenoptera: Braconidae) from pistachio twig borer moth (Kermania pistaciella Amsel (Lep.: Tineidae)) in Gaziantep. Turkish Journal of Zoology. 43 (4): 388-392.

Bolu, H., 2002. Güneydoğu Anadolu Bölgesi Antepfıstığ 1 Alanlarındaki Böcek ve Akar Faunası Üzerinde Araştırmalar. Türk. entomol. derg., 26 (3): 197-208.

Davatchi, G.A. 1958. Sur Quelques Insectes Nuisibles Au Pistachier En İran. Revue de Pathologie Vegatale et Entomologie Agricole de France. Tome XXXVII. No: 1 Paris; $166 \mathrm{~s}$.

Günaydın, T. 1978. Investigations on Insect Species, Biology, Descriptions, Spread and Economical Importation pistachio areas in Southeastern Anatolia Region Turkey (E. Ü. Agricultural Faculty Plant Production).

Küçükarslan, N. 1966. Pistachio of Harmful branch Moth (Kermania pistaciella Amsel) (Lepidoptera: Oinophilidae) of Biology and Chemical Control. Sabri A. Ş. Basımevi. İstanbul, $64 \mathrm{~s}$.

Şimşek, A. and H. Bolu, 2016. Diyarbakır ili Antep fistığ 1 (Pistacia vera L.) alanlarındaki yararlı böcek faunasının belirlenmesi. Bitki Koruma Bülteni. 56 (3): 267-281.

Özgen, İ., Bolu, H. and A. Beyarslan 2012. Chelonus flavipalpis Szepligeti, 1896 and Mirax rufilabris Haliday, 1833 (Hymenoptera: Braconidae): Two New Larva-Pupa Parasitoids of pistachio twig borer Kemania pistaciella Amsel, 1964 (Lepidoptera: Oinophilidae) with the parasizitization ratios from Turkey. Mun. Ent. Zool. 7 (1): 238-242.

Yanık, E. and Y. Yıldırım, 2016. Effectiveness of mass trapping for control of the pistachio twig borer, Kermania pistaciella. Bulletin of Insectology 69 (1): 35-40. 